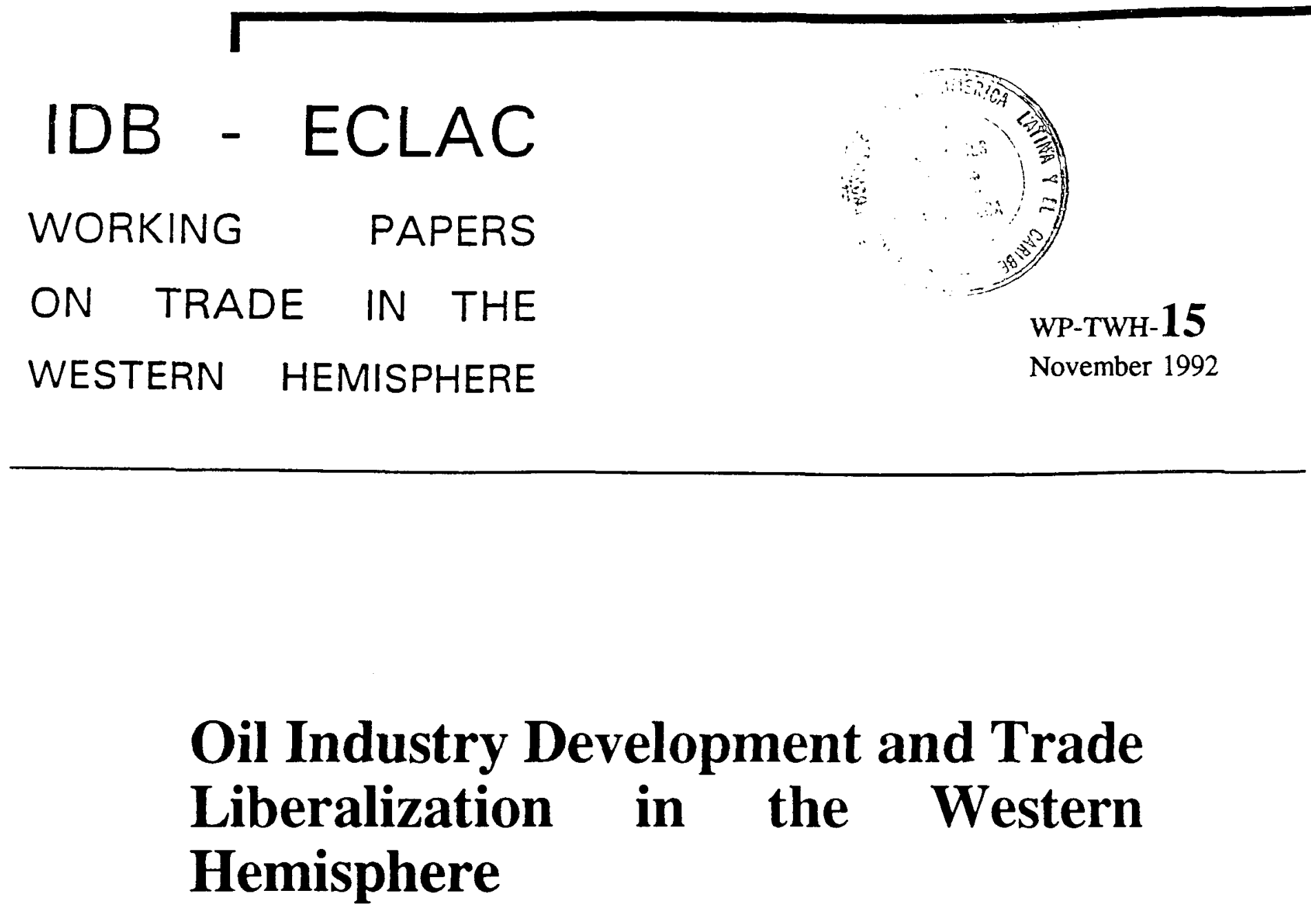

Stephen J. Randall

INTER-AMERICAN DEVELOPMENT BANK

UNITED NATIONS ECONOMIC COMMISSION FOR LATIN AMERICA AND THE CARIBBEAN 


\section{Oil Industry Development and Trade and Investment Liberalization in the Western Hemisphere}

A number of developments in the past several years have raised important questions about the future of trade and investment patterns in the western hemisphere, not least of all in the oil industry. The oil industry is especially important because of the blend of strategic with economic significance, although it might well be argued that the factors that influence oil investment and trade are distinct from those factors that determine the movement of many other commodities, from raw materials to agricultural and manufactured goods. The evidence suggests that for the past seventy years the main factors determining oil investment and trade have been the availability of resources that can be extracted at profitable levels; the security of the investment climate in the producing area; the level of world prices; the availability of technology. The historical record also suggests another conclusion. If the past shapes the present and future, access to strategic raw materials will remain a major foreign policy objective for the United States in the Western Hemisphere, and a critical part of all trade negotiations will be investment liberalization. The critical developments of the past decade include: the implementation of the Canada-United States Free Trade Agreement in 1989; current negotiations on the establishment of a North American Free Trade Agreement to include Mexico; the significant trend toward privatization of the oil industry in a number of Latin American countries, and the Enterprise for the Americas Initiative launched by United States President George Bush through the Inter-American Development Bank.

These hemispheric changes have been taking place within a larger context in which the Cold War that had created a bipolar world for the past forty years has largely ended, the Soviet Union has disintegrated into economically weak and politically fractionalized republics, and the influence of the former USSR on international relations has reached an all-time nadir since the Russian Revolution of 1917. Hemispheric economic changes have also occurred within the framework of a Latin American effort to recover from the lost decade of the 1980s, which were marred by massive debt and debt-restructuring problems, as well as a troubled Uruguay Round of GATT discussions that continue to falter on such major issues as agricultural subsidies.

This paper explores historical and recent trends in the oil industry in the western hemisphere, with particular attention to the implications of trade and investment liberalization for the industry. The paper is divided into the following sections: first the place of the oil industry in the Canada-United States Free Trade Agreement is examined within a larger framework of the historical evolution of United States foreign oil and national security policy; second, the development of the Mexican oil industry and the place of oil in the current NAFTA discussions is explored; third, the paper turns to an overview of the development of the oil industry in Latin America, with particular attention to the historical place of the state and private sectors, the role of foreign investment and the recent trend toward privatization and trade liberalization. Finally, the paper examines the recent Enterprise for the Americas Initiative of President Bush and the Inter-American Development Bank. 


\section{I: Oil and the Canada-United States Free Trade Agreement}

Negotiation of the Canada-United States FTA created one of the most intense domestic political debates in Canadian history, with discussion revolving around issues of Canadian sovereignty and identity. Central to that debate in some circles was the issue of Canadian control over its natural resource base. Coming shortly after a heated debate in Canada and in Canadian-American relations in the 1970s and 1980s over the level of foreign investment in the Canadian oil industry, the establishment of a National Energy Board, of Petro-Canada in 1975, and then a controversial National Energy Policy, it was inevitable that the oil industry would be a central feature in any discussion of a bilateral free trade agreement between Canada and the United States.

Neither the Canada-United States FTA nor the hemispheric debate can be understood separate from the historical evolution of United States global oil policy. Since at least the first World War, security of access to sources of petroleum, along with adherence to the general principle of equality of treatment for United States trade and investment, were central tenets of United States foreign economic and oil policy, including in Canada and other producing areas of the western hemisphere.

Mexico and Canada had by the early twentieth century become the main recipients of United States direct foreign investment, although in the case of Canada significant investment in the oil industry did not come until after World War II and the development of the Leduc fields in Alberta. After the 1920s, United States-based multinational oil firms, frequently with significant support from the Department of State and the Department of Commerce, pressed into other areas of Latin America, most significantly Venezuela, Colombia and Peru; they also gained access to Middle East resources, beginning with the entry in the late 1920s into the Turkish Petroleum Company (later the iraq Petroleum Company) of a United States consortium of firms. Success in the Turkish instance was followed by success in Kuwait, Bahrain, Saudi Arabia and Iran, as well as in the Dutch Empire in Indonesia and the British Empire in Burma.

The growing importance of oil to the major industrial and military states, the onset of World War II and then the Cold War, combined with periodic fears of shortages and even domestic oil exhaustion, highlighted the strategic importance of petroleum supplies, in particular those that were in geographic proximity to the United States and hence likely to be more secure in the event of wartime disruption of international trade patterns. Nationalization, in whole or in part, of oil resources and foreign operations in a number of Latin American and Middle East countries, beginning with Bolivia's nationalization of Standard Oil of Bolivia in 1937 and Mexico's more sweeping nationalization of most foreign-owned operations the following year, underlined the vulnerability of United States-based oil multinationals to economic nationalism. Concern over oil security led the Franklin Roosevelt administration to establish in 1943 the short-lived Petroleum Reserves Corporation. In the aftermath of World War II, the issue of oil security was heightened by Cold War bipolarism and the shift of the United States' position from net exporter to net importer of crude oil. By the 1980 s $40 \%$ of U.S. oil imports were derived 
from Middle East sources. ${ }^{1}$ The formation of OPEC in 1960, the Arab-OPEC oil embargoes in 1973 and 1979-80, which disrupted supplies and played havoc with energy prices, logically exacerbated that sense of insecurity and led the United States to establish a strategic petroleum reserve in the 1970s as well as to continue its traditional policy of security of access to foreign supplies. $^{2}$

Historically, in United States foreign oil policy there was also a long standing tension between advocates of unrestricted foreign imports and those who sought to maintain a viable domestic oil industry against what were considered cheap imports. This tension tended to pit the international oil industry (the majors), the Department of War (Defense after 1947) and the Department of State, which sought to maximize overseas access and development, against the large domestic producers, which sought to restrict oil imports in order to maintain comparatively higher prices for domestic production. In this debate the issue of national security was often played two ways. The Department of State, the Department of War, the Federal Oil Conservation Board in the 1920s and, at times, the Department of the Interior, contended that United States national security would be best protected by exploiting foreign sources of supply and conserving domestic sources. Domestic producers, on the other hand, argued that if domestic prices were driven down it would be difficult to maintain a viable domestic industry, which was the critical factor in supply in the event of national emergency such as war. The main political ally of the domestic producers was Congress, because of the leverage enjoyed by such major producing states as Texas and California. That tension in the making of U.S. foreign oil policy remains in the present, and the concern over potential American protectionism as well as interventionism abroad are factors that have shaped Canadian, Mexican and other Latin American trade and investment strategy.

These international developments, combined with increasing levels of United States investment in Canada and growing Canadian dependence on the U.S. market, led to an intensification of Canadian economic nationalism in the course of the 1960s through the early 1980 s, followed by a sharp shift toward free market economic policies in the United States under President Ronald Reagan and in Canada under Conservative Prime Minister Brian Mulroney.

${ }^{1}$ Shahram Chubin, "U.S. Security Interests in the Persian Gulf in the 1980s, " Daedalus, 247 (1980).

${ }^{2}$ On United States foreign oil policy see among an extensive literature in the field: Stephen J. Randall, United States Foreign Oil Policy, 1919-1948: for Profit and Security (Montreal: McGill-Queen's University Press, 1985); David S. Painter, Oil and the American Century (Baltimore: Johns Hopkins University Press, 1986); Gerald D. Nash, United States Oil Policy 1890-1964 (Pittsburgh: University of Pittsburgh Press, 1968); David Miller, Search for Security: Saudi Arabian Oil and American Foreign Policy (Chapel Hill: University of North Carolina Press, 1980); John Blair, The Control of Oil (New York: Pantheon, 1976); Stephen D. Krasner, Defending the National Interest: Raw Materials Investment and U.S. Foreign Policy (Princeton: Princeton University Press, 1978). 
This shifting political paradigm between statism and free market economics provided much of the background to the negotiation and debate over the Canada-United States free trade agreement.

One of the critical objectives of the United States was to implement an agreement that would reduce the likelihood of something like the NEP being implemented in the future, even though that program had been largely dismantled by the time the FTA negotiations began in earnest. One objective was to restrict government price control, since the NEB had established domestic oil price controls in 1973 in the aftermath of the Arab-OPEC embargo, using the basic principle that prices for exports were to be higher than for domestic consumption, a price differential that was achieved through the application of export duties. The combined intent of the National Energy Board's activities, the Foreign Investment Review Agency and the NEP was to strengthen Canadian control and ownership over the oil industry and to attempt to ensure that the benefits of increases in world oil prices accrued to the Canadian industry and society, while Canadian consumers simultaneously enjoyed the benefits of lower domestic prices. The NEP continued a price differential structure, export controls. production taxes and a Petroleum Incentives Program. ${ }^{3}$

Part of the rationale of such initiatives was to make the oil industry more responsive to Canadian needs, in other words paralleling an orientation that had existed in Mexico since 1917. A primary objective of policy was to increase the level of Canadian ownership in the industry through, for example, Petro-Canada's acquisition of the Canadian subsidiaries of all or portions of some foreign-owned firms, specifically Petrofina Canada and BP Canada in 1981-82, and through the Petroleum Incentives Program, which involved financial assistance to Canadian firms for oil and gas exploration and development. There was particular interest under the NEP in encouraging frontier development. To that end the federal government established a new royalty system that favoured frontier production as well as the activities of Canadian firms in those areas. In fact, the federal government restricted licenses for frontier projects to those firms with at least $50 \%$ Canadian equity.

The reaction from the oil industry, the Alberta Government and the United States to the National Energy Program was highly negative, but that reaction was muted by the defeat of the Liberal Government in 1984 by the Conservatives and the shift toward an increased emphasis on privatization and free market economics, although the NEP was widely blamed for the

${ }^{3}$ Canada, Department of Energy, Mines and Resources, The National Energy Program 1980 (Ottawa: Supply and Services Canada, 1980); The National Energy Program Update 1982 (Ottawa: Supply and Services Canada, 1982); John F. Halliwell, Mary E. MacGregor, Robert N. McRae, André Plourde, Oil and Gas in Canada: the Effects of Domestic Policies (Toronto: Canadian Tax Foundation, 1989); andré Plourde, "The NEP Meets the FTA," Canadian Public Policy, XVII (1991), 15-24; Robert N. McRae, "A Major Shift in Canada's Energy Policy: The Policies and Impact of the National Energy Program," The Journal of Energy and Development, VII, No. 2 (1982), 173-98. 
dramatic economic downturn in the oil industry in the 1980s. ${ }^{4}$ The main criticism of the NEP by the Reagan administration concerned the investment restriction provisions. As one analyst concluded, the Reagan administration's response demonstrated the difficulty Washington sometimes experiences with the need to address specific bilateral issues in Canadian-American relations and the broader open door objectives of U.S. foreign economic policy. U.S.-owned companies responded to the NEP by appealing to the Reagan administration for support, by divesting themselves of Canadian assets, cutting back exploration and drilling, or reorganizing to take advantage of NEP requirements favouring Canadian firms. ${ }^{5}$

That was the context in which the negotiations for a Canada-United States free trade agreement began and reached conclusion. Energy matters logically constituted a significant component of the FTA, not solely because of the political debate that preceded the FTA but also because of the value in energy product exports, which had reached $\$ 10$ billion by the late 1980s, most to the United States.

The energy provisions of the FTA are encompassed by Chapter 9. From a Canadian government perspective, the main objective of Chapter 9, indeed of the entire FTA, was to secure Canadian exports in the vitally important American market. At the same time, Canadian negotiators sought to maintain, for political and economic reasons, some consistency between the FTA and the national policies that had evolved over the previous twenty years as well as with the GATT, even though the basic program of the NEP had been dismantled by the Conservative Government by the time FTA negotiations began. Consequently, the energy provisions of the FTA recognized the mutual interest of both countries in ensuring access to each other's market and security of supply, providing for faimess of treatment in the application of controls, and recognizing that national security might require continued monitoring and licensing of exports.

${ }^{4}$ Gilbert Jenkins, Oil Economists' Handbook, 4th edition (London and New York: Eslevier, 1986), p. 3.

${ }^{5}$ Edward Wonder, "The US Government Response $t$ the Canadian National Energy Program," Canadian Public Policy, VIII (1982), 480-93. Wonder notes that "the transnational impact of Canadianization raised a number of thorny policy questions. The NEP appeared to be linked to a number of unfriendly takeover attempts by Canadian firms directed at US parent companies." He cites the example of the pursuit of Conoco by Seagrams. As Wonder indicates, the possible hostile takeover dimension was the aspect that most concerned members of the United States Congress, which has consistently been more protectionist than the White House or State Department on oil issues. The House Committee on Government Operations suggested the establishment of an American equivalent of FIRA. See the U.S. House of Representatives, Committee on Government Operations, The Adequacy of the Federal Response to Foreign Investment in the United States (1980). 
Article 902 pertained to import and export restrictions. the clause reaffirmed the application of GATT provisions, including a prohibition on minimum export-price requirements and, "except as permitted in enforcement of countervailing and antidumping orders," minimum import-price requirements. The article allowed restrictions of imports of energy goods from a third party, provided that in the event such restrictions were applied there would be consultation to avoid "undue interference with or distortion of pricing, marketing and distribution arrangements in the other Party."

Article 903 prohibited the application of export duties or taxes on any energy good not also applied to domestic consumption. At the same time Article 904 prohibited energy export restrictions if such restrictions reduced exports below the level prevailing in the previous 36 month period, and negated the application of higher prices for exports than for products destined for domestic consumption. No restriction of energy exports was allowed that would "require the disruption of normal channels of supply to the other Party or normal proportions among specific energy goods supplied to the other Party...."

Article 906 recognized the legitimacy of government incentives for energy resource development "in order to maintain the reserve base for these energy resources." Pursuant to that notion, Article 907 pertained to national security measures, which allowed either party to restrict trade in an energy good in order to supply a military establishment, respond to armed conflict, implement agreements relating to the non-proliferation of nuclear weapons, or to respond to "direct threats of disruption in the supply of nuclear materials for defense purposes." Annex 902.5 contained one provision of importance for oil trade, to the effect that the United States would exempt Canada from the 1979 prohibition on the export of Alaskan oil, to a maximum volume of fifty thousand barrels per day, subject to the condition that the oil be transported to Canada not from Alaska but from a "suitable location" within the lower 48 states. Finally, Article 905 provided for consultation in the event either party believed that a regulatory action resulted in discrimination against trade in energy goods. ${ }^{6}$

Clearly, the FTA prohibits the type of government price controls that were introduced in the 1970s under the NEP, involving minimum export price requirements (Article 902) or export taxes (Article 903). Yet, if market forces were to produce a situation in which similar results ensured or in which there was a price difference between domestic and export markets, there would be no violation of the agreement or of GATT regulations. One possible loophole in the prohibition against domestic price controls on crude oil is contained in the provision in Article 904 of the FTA, which allows the exporting country to introduce export restrictions under Article XX of the GATT. That Article stipulates that such restrictions are permissible if they are intended to "ensure essential quantities of such materials to a domestic processing industry during periods when the domestic price of such materials is held below the world price as part of a government stabilization plan," again, as long as such provisions are not

${ }^{6}$ Canada, Department of Energy, Mines and Resources, The Canada-U.S. Free Trade Agreement and Energy: An Assessment (Ottawa: Supply and Services Canada, 1988). 
discriminatory. ${ }^{7}$ At least some authors have concluded that this allows the application of quantitative restrictions to enforce domestic price controls on raw materials. ${ }^{8}$ At the same time, unless they are the product of market forces, export price differentials would be clearly prohibited. As well, under the FTA's prohibition against government imposition of direct export taxes, producers would be the first beneficiary of any additional revenues that resulted from market driven export price increases, although government could tax those profits back. Further, given the basic guarantee under the FTA of uninterrupted supply of energy products, the NEP practice of distinguishing between certain categories, such as heavy versus medium and light crude oil would not likely be allowed under the FTA.'

Investment controls and enhanced Canadian ownership were two of the main objectives of Canadian government energy policy in the 1970s and early 1980s. As noted earlier, the Petroleum Incentives Program favoured Canadian over foreign-owned subsidiaries. It has been suggested that the FTA did little to alter a system that gave preferential access to oil resources to Canadian firms. Philip Verlager, Jr., of the Washington Institute of International Economics, for instance, argued in the Energy Journal in 1988 that the absence of firm investment guarantees of equal treatment was a "serious omission."

Verlager contended that a country could not logically pursue a policy of free trade in energy but adhere to a restrictive policy on foreign investment, ${ }^{10}$ something which should be unacceptable under the "national treatment" principle of the FTA (and of GATT). Nonetheless, although the FTA permits subsidies for exploration and development, such subsidies under Article 1602 of the FTA would have to be applied in a non-discriminatory manner between foreign-owned and Canadian companies. The terms of the FTA also made unacceptable special treatment for Canadian firms in encouraging frontier area exploration and development. ${ }^{11}$ On the whole, then, the basic intent of the Reagan administration to achieve a maximum degree of access to Canadian oil resources, without the restrictions of Canadian economic nationalism embodied in FIRA and the NEP, an objective which was consistent with long-standing United States foreign economic policy, was largely realized under the FTA, and it was the desire of the U.S. Government to work toward the removal of any restrictions that remained.

${ }^{7}$ Plourde, "NEP meets FTA," p. 16.

${ }^{8}$ Frieder Roessler, "GATT and Access to Supplies, " Journal of World Trade Law, 9 (1975), 25-40; Edmond McGovern, International Trade Regulation: GATT, the United States and the European Community (Exeter: Globefield Press, 1986).

${ }^{9}$ Plourde, "NEP meets FTA," p. 18.

10"An American Perspective," the Energy Journal, 9, no. 4 (1988), 99-101.

${ }^{11}$ Plourde, "NEP meets FTA," pp. 19-20. 
Both parties, some suggest, thus achieved their objectives in the energy area in the FTA, with Canada obtaining more secure access to the American market, with less American protectionist intervention. Such American legislation as the 1932 and 1959 import duties on foreign oil could not, in other words, apply to imports from Canada under the FTA. Yet, at the time the FTA was negotiated, American protectionism in the area of oil was minimal, amounting to slightly over 5 cents per barrel on heavy crude, 10 cents per barrel on light crude, and 52 cents per barrel on gasoline and jet fuels. ${ }^{12}$ Thus it is evident that trade liberalization alone, without investment liberalization will not accomplish the objectives of U.S. policy, and it is important to note that in the Mexican negotiations as well as in the Enterprise for the Americas Initiative, investment liberalization is an important target.

What effect the FTA will have on Canada-United States energy trade remains controversial. If the U.S. objective was security of access to Canadian resources and a national treatment principle, that objective was largely realized, but the downturn of the economies in both countries in the 1989-92 period has made it difficult to make any realistic judgement of likely investment patterns. Indeed, what evidence there is form a global perspective is negative, since there has been a diversion of capital from Canada, which is a high cost producer, to countries such as Colombia and Bolivia, where major discoveries have been made by firms otherwise active in Canada, specifically BP in Colombia in 1991. Trade liberalization itself is of little assistance in determining the likely developments in the oil (and natural gas) trade between Canada and the United States, since even prior to the FTA, energy trade was one of the sectors in Canadian-American cross border movement that was essentially free of duties. ${ }^{13}$

For Alberta exports of natural gas to the California market, for instance, difficulties that have arisen since the FTA have derived from disputes over pricing and the length of supply contracts. In the short period the agreement has been in place, experience suggests that both countries will likely continue to utilize what regulatory powers they retain to control exports and imports in their respective national interests. ${ }^{14}$

${ }^{12}$ Shelly P. Batram and R.H. Lock, "The Canada/United States Free Trade Agreement and Trade in Energy," Energy Law Journal, 9 (Summer 1988), 327-87. John Ryan, "The Effect of the Free Trade Agreement on Canada's Energy Resources," The Canadian Geographer, 35 no. 1 (1991), 70-82.

${ }^{13}$ Robert McRae,Energy Trade Shocks: The Impact on Canadian Economic Activity," in David L. McKee, Canadian-American Economic Relations: Conflict and Cooperation on a Continental Scale (New York: Praeger, 1988), pp. 31-46.

${ }^{14}$ John N. McDougall, "The Canada-US Free Trade Agreement and Canada's Energy Trade," Canadian Public Policy, XVII (1991), 1-2. 


\section{II: Canadian Oil Trade and Investment:}

Canadian petroleum trade with the United States during the past thirty years has been characterized by a dominance of Canadian exports, and there is no indication that situation will change under an altered trade regime, including one in which there is a North American Free Trade Agreement. As the Appendices indicate, the United States has throughout this period been the main, indeed almost sole, market for exports of Canadian crude and refined oil products. Canadian crude oil production, exports to the United States, and imports peaked in 1973. In that year Canada produced 104.1 million cubic metres of crude oil, imported 52.2 million cubic metres, and exported 66.8 million cubic metres to the United States, representing $64.2 \%$ of Canadian crude oil production (over $90 \%$ of all exports) and $9.3 \%$ of total United States consumption. That was the highest level of dependency on Canadian exports the United States has reached. From the 1973 oil crisis until 1983 Canada was a net importer of oil, essentially as a result of government regulated exports. Since 1973, Canadian crude oil exports to the United States have ranged from $7.5 \%$ of U.S. consumption in 1974 to a low of $1.3 \%$ in 1980 during the second Arab-OPEC oil crisis. In 1975 Canada's crude oil exports were valued at $\$ 3.1$ billion; in 1985 the value peaked at $\$ 5.9$ billion only to decline again the following year to $\$ 3.8$ billion. ${ }^{15} \quad$ Since the movement toward deregulation in the mid-1980s, the level of exports to the U.S. has increased once again, reaching 33.6 million cubic metres or $4.5 \%$ of U.S. consumption in 1986, and 37.5 million cubic metres in 1990. In terms of United States dependency on Canadian crude oil exports, the statistics clearly indicate that in terms of total U.S. imports Canadian-produced oil has played a minor role in the American market, although since 1981 Canada has been the largest single supplier. Further, when examined in terms of particular U.S. Petroleum Administration for Defense Districts, especially in District II, however, U.S. reliance on Canadian oil has been much higher, making any curtailment of supplies during national/international emergencies of considerable strategic significance to the United States, even though Canada's oil reserves in the 1980 s (0.60\% of world reserves) pale by comparison with other areas of the world. ${ }^{16}$

Canadian exports relied overwhelmingly on the U.S. market, but Canadian imports tended to have a strong dependency on Venezuela and Arab-OPEC producers. Imports peaked in 1973, when Canada imported more than 50 million cubic metres of crude oil, almost half of

\footnotetext{
${ }^{15}$ Figures for value are from Brian Scarfe, "Energy Investment and Security of Supply," in G. Campbell Watkins, ed., Petro Markets: Probing the Economics of Continental Energy (Vancouver: Fraser Institute, 1989), p. 182.

${ }^{16}$ The best treatment of this subject is by André Plourde and Leonard Waverman, "Canadian Energy Trade: the Past and The Future," in G. Campbell Watkins, ed., Petro Markets: Probing the Economics of Continental Energy (Vancouver: Fraser Institute, 1989), pp. 141-80. Data is drawn from Plourde and Waverman and Statistics Canada, the Crude Petroleum and Natural Gas Industry, various years. for world oil reserves see DeGolyer and McNaughton, Twentieth Century Petroleum Statistics, 1988 (Dallas, 1989), p. 1.
} 
which came from Venezuela and the remainder from other OPEC producers. By 1976 Canada was importing several million cubic metres of crude oil from the United States, and Mexico and the United Kingdom began to make significant contributions from its North Sea production, passing OPEC as a source of supply for Canada in 1986. In 1976 Canada expended $\$ 3.3$ billion on crude oil imports. In 1985, the first year of deregulation, the expenditure was $\$ 6.3$ billion. $^{17}$

\section{II: Canadian Trade in Refined Products:}

The situation with refined oil products differed in several critical ways from that pertaining to crude oil. In the 1970s there was considerable international expansion of refining capacity and a corresponding decline in demand in the U.S. market for Canadian refined products. Canadian production of refined products peaked not in 1973 as in the case of crude oil but in 1979, when total production reached 114.7 million cubic metres. Canadian production then declined through the 1980s to a low of 85.8 in 1986. Exports remained more constant than production levels in the same years, reaching a peak in 1984 of 16.7 million cubic metres. Exports to the United States peaked in the same year at 15.9 million cubic metres, which represented $1.7 \%$ of total U.S. consumption. At the same time Canadian imports of refined oil products climbed steadily in the course of the 1980s as deregulation in Canada (1985) and the United States took effect, rising from 1.4 million cubic metres in 1979 to 8.2 million in 1986, but this was less than $10 \%$ of Canadian production.

There was a shift in the sources of Canadian refined imports, with increasing reliance in the 1970s and 1980s on the United States and a decline in the relative importance of OPEC supplied refiners in the Caribbean. ${ }^{18}$ In short, for both crude oil and refined products the United States has remained an important market for Canadian production and the United States a growing source of supply for refined oil product imports in the past decade. Analysts suggest that Canada, though the second largest energy producer among the OECD countries, cannot long remain an important supplier of oil and oil products to the United States simply because Canada does not have adequate levels of low-cost conventional oil. That situation would alter only if prices rose sufficiently to make economical the exploitation of higher cost tar sands and heavy oil. ${ }^{19}$

\footnotetext{
${ }^{17}$ Plourde and Waverman, "Canadian Energy Trade," pp. 154-55.

${ }^{18}$ Plourde and Waverman, p. $160-62$.

${ }^{19}$ Robert N. McRae, "Canadian Energy Development," Current History, 87 (March 1988),
} 119. 


\section{IV: Canadian Investment:}

What has happened to the issue of Canadian ownership in the Canadian oil industry in this time period? The record suggests that the principle of Canadianization effectively ended under the Conservative Government well before the FTA was negotiated. Illustrative examples include the sale of Canadian-owned Nova's share in Husky Oil to a Hong Kong interest. Sulpetro of Calgary was auctioned in 1987 to Imperial Oil; Ocelot was sold to Mosbacher of Texas; Amoco outbid TransCanada Pipelines for Dome Petroleum in 1987, although TCPL acquired Encor, Dome's Canadian subsidiary. ${ }^{20}$

Direct foreign investment in the Canadian oil and gas industry has not shown significant change since 1985 , as the following table illustrates.

Canada's International Investment Position

FDI in Canadian Oil and Gas ${ }^{21}$

\$millions (CDN)

$\begin{array}{llllcc}\text { Year } & \text { Total } & \text { USA } & \text { UK } & \text { Other EEC } & \text { Japan } \\ & & & & & \\ 1990 & 21,290 & 13,799 & 3,531 & 2,157 & 146 \\ 1989 & 19,630 & 13,758 & 2,211 & 2,042 & 89 \\ 1988 & 20,187 & 14,475 & 2,134 & 1,808 & 95 \\ 1987 & 19,249 & 14,658 & 1,561 & 1,553 & 487 \\ 1986 & 18,894 & 14,417 & 1,315 & 1,919 & 490 \\ 1985 & 20,542 & 16,504 & 1,199 & 1,642 & 477\end{array}$

During the same period Canadian direct investment in oil and natural gas has demonstrated almost no alteration, and the United States has remained the main target for Canadian investment in the industry, as illustrated in the following table:

${ }^{20}$ Michel Duquette, "Domestic and International Factors Affecting Energy Trade," in S.J. Randall, ed., North America Without Borders? the Integration of Canada, the United States and Mexico (Calgary: University of Calgary Press, 1992).

${ }^{21}$ Canada, Statistics Canada, Canada's International Investment Position (Ottawa, 1991). 
Canada's International Investment Position

Canadian DFI Abroad

In Oil and Natural Gas

$\$$ millions $(\mathrm{CDN})^{22}$

$\begin{array}{llr}\text { Year } & \text { Total Petroleum } & \text { USA } \\ & & \\ 1990 & 6,011 & 4,292 \\ 1989 & 5,738 & 4,184 \\ 1988 & 5,365 & 3,850 \\ 1987 & 5,220 & 3,474 \\ 1986 & 6,823 & 4,303 \\ 1985 & 7,684 & 5,637\end{array}$

On the whole, then, in the area of oil development and trade, tariff barriers were marginal impediments in comparison to government regulation. What was critical was the shift to market forces that preceded the FTA.

\section{V: Canada, the United States and Mexico: Oil and a North American Free Trade Agreement}

The place of oil in a North American free trade area must be understood in its larger historical context. Since The Mexican Revolution, foreign investment has been a sensitive political issue in Mexico. In the Mexican Constitution of 1917, one of the most radical in the western hemisphere, subsoil mineral resources were reserved to the state and Article 27 provided for the right of expropriation in the national interest. The lengthy and often emotional diplomatic disputes with foreign interests, primarily American, that arose from debate over the application of Article 27 lie outside the main focus of this paper, but they provide an important part of the context in which NAFTA was negotiated.

The United States began importing crude oil from Mexico in 1918, and although the relative importance to the United States declined in the late 1920s through World War II, especially after Mexico nationalized the oil industry in 1938 and established Pemex; that situation altered in the 1970s with the Arab-OPEC embargoes. By 1987, U.S. imports of

\footnotetext{
${ }^{22}$ Canada, Statistics Canada, Canada's International Investment, Canadian Direct Investment Abroad (Ottawa, 1991).
} 
Mexican crude stood at 219 million barrels, down from the peak of 279 million in 1983 . By the 1980s almost equal amounts of imported crude were derived from Mexican and Canadian sources. Only Saudi Arabia exceeded their national totals, although taken together OPEC producing countries in 1987 accounted for 876 million barrels of total U.S. imports of 1.7 billion. ${ }^{23}$

Although Mexico has thus sought to carve an independent path in the oil industry, it has of necessity been a player on the international scene. Its estimated crude oil reserves in 1987 were over 54 billion barrels, only some $10 \%$ of the OPEC countries, but giving it twice the estimated reserves of the United States, and ranking it only slightly behind all of Eastern Europe. By 1991 its proven reserves had risen to 65.5 billion barrels. In 1987 it produced 2.5 million barrels of oil a day (and continued to produce at that level into 1990), representing $4.5 \%$ of world production, well ahead of Canada at 1.5 million, Venezuela at 1.6 million, and ahead of all countries in the Middle East except Saudi Arabia's 3.9 million, but behind the 10 million of the United States. With rapidly rising domestic demand, however, during the 1960s Mexico became a net importer of oil, and that remained the situation until the development of new reserves in the southeast of the country in the late 1960 s. By the late 1970 s that area accounted for over $76 \%$ of Mexican production, but the main reserves still lie beneath the shallow waters of the Gulf of Campeche, and the oil produced there is a light, higher grade than the heavier, more sulphurous crude (known as Maya) from Tabasco and Chiapas in the south. ${ }^{24}$ Of its production, Mexico exported 1.2 million bbl/day in $1990 .{ }^{25}$

United States officials throughout this century have seen the necessity of Mexico playing a strategic role in the event of supply disruptions during international crises; not only does Mexico have large scale production and reserves, but its geographic proximity and land ties to the United States, like those of Canada, make the movement of oil in the event of emergency less vulnerable. The FTA, combined with the 1974 agreements under the International Energy Agency, provides (Article 908) the assurance of Canadian oil supplies to the United States, but no such guarantee currently exists for Mexico, which has considerably higher long-term potential.

In the 1980s Mexican Presidents Miguel de la Madrid and Carlos Salinas de Gortari moved significantly toward trade and investment liberalization, in what has come to be

${ }^{23}$ DeGolyer and McNaughton, Twentieth Century Petroleum Statistics, pp. 58-59.

${ }^{24}$ Grayson, p. 428. The Economist, Intelligence Unit, Mexico

${ }^{25}$ DeGolyer and McNaughton, Twentieth Century Petroleum Statistics, pp. 1, 2. Pemex data for 1989-90. 
known as the "Salinas opening." ${ }^{26}$ In the course of the decade Mexico reduced its astronomical foreign debt, which had reached $\$ 10.75$ billion in 1978 , by cutting spending, reducing imports, encouraging exports, combatting inflation, effectively removed almost all tariff barriers to trade by 1989 , moved toward investment liberalization in some areas, and radically reduced the number of government-owned enterprises in a large scale shift toward privatization. In 1986 Mexico joined GATT as part of its move toward trade liberalization. Encouragement of non-oil exports resulted in an increase of that sector from $-1.9 \%$ in 1982 to $37 \%$ in 1986 . Between 1982 and 1988 the nominal deficit as a percentage of GDP was reduced from $16.2 \%$ to $12.3 \%$, even though the 1985 earthquakes resulted in an abandonment of efforts at stabilization. ${ }^{27}$ In the area of privatization, by 1990 only 496 of 1,155 state enterprises that existed in 1983 were still state-owned. Unfortunately, with the decline in oil revenues owing to the fall in world oil prices, which reduced oil revenues from $12.2 \%$ of GNP in $1982-85$ to $7.5 \%$ in 1988 , curtailed spending has fallen disproportionately on important areas such as public investment, education and health, which Mexico cannot afford to neglect if it is to move into first world economic circles. ${ }^{28}$

The movement of Mexico toward closer and more positive relations with the United States, in particular the initiation of free trade negotiations in 1989, in which Canada subsequently joined, needs to be understood in the context of long term conflicts and tensions between the two nations and a general lack of Canadian official interest historically in Mexico. For much of the twentieth century Mexico and the United States have feuded and negotiated over border questions, including legal and illegal immigration from Mexico to the United States, environmental questions, drug trafficking, water control, access to such natural resources as oil and natural gas, and labour rights. Those twentieth century developments added to a longer historical antagonism toward the United States that derived in large measure from the Mexican loss of half its national domain to the United States by war in the mid-nineteenth century. Thus, the Salinas overture toward the North American market has strong political overtones as well as economic significance. As one commentator observed over a decade ago, it is difficult for Mexicans to transcend their historical past. ${ }^{29}$

\footnotetext{
${ }^{26}$ Robert Pastor, "Post-Revolutionary Mexico: The Salinas Opening," Interamerican Studies and World Affairs, vol. 32, No. 3 (Fall 1990), 1-22.

${ }^{27}$ Banco de México, Indicadores Económicos, Septiembre 1989; Williamson, ed., Latin American Adjustment, p. 156.

${ }^{28}$ John williamson, ed., Latin American Adjustment: How Much Has Happened? (Washington: Institute for International Economics, 1990), p. 316.

${ }^{29}$ New York Times, 19 February 1979, cited in Grayson, "Oil and U.S.-Mexican Relations," p. 437.
} 
United States interest in Mexico as well as new Canadian interest is closely tied to Mexico's oil and natural gas industry. The Middle East oil shocks in the 1970s and early 1980s underlined the vulnerability of the United States to the curtailment of supplies from that region and rekindled the perception that it was strategically essential to achieve closer relations with one's resource rich neighbours. The dramatic expansion of Mexico's proven reserves of oil and gas in the 1970s coincided with that perception.

In 1979, when Senator Edward Kennedy was chairman of the Subcommittee on Energy of the Joint Economic Committee, he linked stimulating Mexican gas production and sales to the United States with improving American access to Mexican oil, in turn strengthening the Mexican economy and reducing Mexican immigration pressures on the United States. The linkage between the natural gas and oil situation in Mexico is especially close because most Mexican natural gas is "associated with oil and must be injected, consumed at home, or exported to prevent loss through flaring." Kennedy also perceived increased Mexican oil production as a means of relieving the dependency of various nations, not solely the United States, on Middle East supplies. Significantly, Kennedy's views were shared strongly by the Pentagon, which was purchasing Mexican oil from Pemex for the Strategic Petroleum Reserve in 1978. The National Security Council by the end of the 1970s saw Mexico as the most promising source of oil, and like Kennedy, saw possibilities of linkages between energy trade and other divisive issues in Mexican-U.S. relations.

There are a complex range of domestic political factors in the United States which account for a growing interest in Mexican resources, not simply an economic motivation, including the desire of some pro-Israel groups to use Mexico as a means to reduce dependency on Arab oil producing nations, ${ }^{30}$ but the politics of energy lie outside the scope of this paper.

On the Mexican side, however, it is still not politically viable to move toward total liberalization of investment in the oil industry even if there is a strong need to generate hard currency earnings through enhanced exports of both oil and non-oil exports. Economically, closer ties with the United States were virtually inevitable given the direction of the Mexican economy in the past two decades. As with Canada, the bulk of Mexican trade has been with the United States. Third option initiatives, as in the Trudeau years in Canada in the 1970s, have not worked to Mexico's economic advantage and have certainly not reduced the importance of the American market for Mexico. In addition, Mexico's massive debt burden in the 1970s and 1980s has heavily involved American financial institutions, and such support is crucial to Pemex's expansion as well. ${ }^{31}$

\footnotetext{
${ }^{30}$ Washington Post, 15 December 1978, cited in Grayson, "Oil and U.S.-Mexican Relations," p. 452.

${ }^{31}$ Grayson, "Oil and U.S.-Mexican Relations," pp. 339-47.
} 
Oil and oil derivative products remain the most important component of Mexican exports, although their relative importance has declined in the course of the past decade. During the 1980s the Mexican National Energy programme set a ceiling of $1.5 \mathrm{~m} \mathrm{bbl} / \mathrm{day}$ on oil exports at the same time that it sought to diversify the country's energy base; government policy maintained high domestic prices for oil and gradually made more oil available for export as conservation and energy diversification took hold. The policy also stipulated that Pemex could not sell more than $50 \%$ of its production to any one country in order to avoid any political entanglements with the United States that might result from an excessive dependence on sales to the American market. By 1980 58.3\% of Mexico's oil exports went to the United States in comparison with $3.9 \%$ to Canada, $7.9 \%$ to each of Japan and France and $12.8 \%$ to Spain. ${ }^{32}$

\section{VI: NAFTA and Mexican Oil:}

It is difficult to isolate oil from the general issues that have confronted the Mexican economy in the 1980s. Overall, after the devaluation of the peso was corrected in 1982, general imports increased in cost and declined in volume through the middle years of the decade, gradually recovering by 1987 . Trade liberalization, the high demand for food products, and a freeze on the peso worked to push up imports in 1988 by $55 \%$. Exports in the mid-decade were stagnant. Non-oil exports rose by $16 \%$, but oil exports fell by $22 \%$ in value as a result of lower world prices and an actual decline in the volume of exports. In 1989 and 1990 Mexico suffered its first negative balance of trade in the decade, in spite of the significant increase in Mexican oil prices in late 1990 occasioned by the Iraq/Kuwait crisis in the Middle East. Imports continued to rise more rapidly than oil and non-oil exports in 1989-90, largely because of the inadequacy of domestic food production and the growth of intermediate goods imports. The perception is that one of the main areas of the Mexican economy that requires action is an increase in inputs in order to increase non-oil exports. ${ }^{33}$

Mexican trade liberalization has been accompanied by only marginal change in the Mexican approach to investment in the oil and petrochemical industries, unlike the situation in Canada, where investment and trade liberalization have been part of the same program. NAFTA provides considerable trade and investment liberalization, including the elimination of tariffs and import restrictions in a number of areas: automobiles, agriculture, fishing, transportation, and most manufacturing, with the exception of direct investment in oil and gas exploitation. Investor-state arbitration has been included, so that disputes between

${ }^{32}$ The Economist, Intelligence Unit, Mexico, Country Profile. 1988-892: Annual Survey of Political and Economic Background. George Grayson, The Politics of Mexican Oil (Pittsburgh: University of Pittsburgh Press, 1980), p. 181.

${ }^{33}$ The Economist, Intelligence Unit, Mexico, Country Profile, 1991-92. Annual Survey of Political and Economic Background. 
investors from a NAFTA country and a NAFTA government may, at the investors request, be settled through international arbitration. ${ }^{34}$

In petrochemicals, although government policy still prohibits foreign ownership of a number of petrochemicals such as ammonia and methanol, during the Salinas administration there had already been investment liberalization, with the result that there are now an estimated 175 foreign companies involved in the production of basic and secondary petrochemicals. In secondary petrochemicals Mexican law allows foreign investment, including ownership, in all areas, including refining, services and technology, with the result that it is believed in Canadian oil circles that there are significant investment and technology sales opportunities in Mexico, since Pemex has set aside more than $\$ 4$ billion U.S. per annum through 1995 for the purchase of oil and gas equipment, exploration and development. Such funds for modernization and restructuring have been made available as a result of the easing of the Mexican debt burden, which had been met partly through Pemex revenues. Canada's position in the Mexican petrochemical market is enhanced by the Canadian Export Development Corporation, which in conjunction with the Canadian Government has secured a $\$ 520$ million line of credit to support Pemex's purchases. ${ }^{35}$

The evidence indicates clearly that there will be continuing pressure on Mexico and on Canada in the coming years from the United States to eliminate investment controls in the oil industry for reasons of ideology, economic advantage and national security. The conclusion of a North American Free Trade Agreement, which involves closer economic integration of the continent, will intensify those pressures. The reliance of both Canada and Mexico on the United States market for their exports and for investment capital will make those pressures difficult to resist in the long term.

\section{VII: The South American Oil Industry and Trade Liberalization:}

Historical and recent patterns in the Latin American oil industry are similar to those that have prevailed in Mexico and Canada, although there are also major differences with the Canadian experience. In general, Latin America passed through a lengthy period in which United States and other foreign capital investment dominated the oil industry. In several countries, including Argentina and Bolivia, the state moved relatively early into the oil sector, establishing in both countries state oil companies roughly comparable to PEMEX in Mexico and Petro-Canada in Canada. Argentina established YPF (Yacimientos Petrolíferos Fiscales) in the 1920s and Bolivia established YPFB (Yacimientos Petrolíferos Fiscales

\footnotetext{
${ }^{34}$ Notes from an address by the Honourable Michael Wilson, Ministry of Industry, Science and Technology and International Trade, August 1992.

${ }^{35}$ Wifrid Laurier University, Trade Development Centre, Doing Business in Mexico (1992), provided courtesy of José Zeilstra.
} 
Bolivianos) in the late 1930s following the nationalization of Standard Oil of Bolivia. All other countries in Latin America have ultimately created national oil companies with varying degrees of control over the industry, making the Latin American model closer to that of Mexico and Canada than the United States. Thus, in 1992 there are approximately seventeen state oil companies in Latin America and the Caribbean: Argentina, YPF; Bolivia, YPFB; Brazil, Petrobras; Chile, ENAP; Colombia, ECOPETROL; Costa Rica, RECOPE; Cuba, CUPET; Ecuador, PETROECUADOR; Jamaica, PCJ; Mexico, PEMEX; Nicaragua, PETRONIC; Paraguay, PETROPAR; Peru, PETROPERU; Surinam, STAATSOLIE; Trinidad and Tobago, TRINTOC; Unuguay, ANCAP; Venezuela, PDVSA. There is also an important regional organization of Latin American state oil producing companies, ARPEL (Asistencia Reciproca Petrolera Estatal Latinoamericana), one of the objectives of which is to reduce the vulnerability of Latin America to international oil shocks through an increase in regional trade in oil and natural gas.

In all of Latin America the establishment of state oil companies was intended to serve as a means to control the levels and degree of influence of foreign investment, to provide an anticipated higher level of return to the nation from natural resources, and to ensure national security.

\section{VIII: Oil Production and Trade:}

Argentina, Ecuador, Peru, Trinidad/Tobago, and Venezuela were the original oil producers in Latin America, all of which were active by 1918. Of those the largest producer was Peru, followed by Trinidad/Tobago, Argentina, and Venezuela. By 1930 those pioneer producers had been joined by Bolivia and Colombia, the latter of which had become a major producer in Latin America, with Standard Oil subsidiary Tropical Oil the sole producing company. By 1930 Venezuela ranked first in production, followed by Colombia and Peru. In 1930 Bolivia achieved commercial levels of production for the first time; Brazil reached that status only in 1940, and Chile followed a decade later. By 1940 Argentina and Trinidad/Tobago had surpassed Peru. By 1960 the ranking continued to place Venezuela well ahead of all other producers, followed by Argentina, Colombia, Trinidad/Tobago, and Brazil. In 1989 the ranking was Venezuela (696 million), Brazil (224 million), Argentina (163 million), Colombia (147 million), Ecuador (101 million), Trinidad/Tobago (56 million) and Peru (47.9 million). ${ }^{36}$

In the pre-1960s Latin America reached those levels of production largely through foreign investment and the subsidiaries of U.S.-based multinationals, although in the preWorld War II years they invested primarily in exploration and development of crude oil for. purposes of export. ${ }^{37}$

\footnotetext{
${ }^{36}$ U.S., Department of Energy, World Oil.

${ }^{37}$ Randall, United States Foreign Oil Policy, p.23.
} 
The main impact of U.S. DFI in the oil industry in the early years and in the lessdeveloped South American countries for much of this century was to stimulate exports of crude oil and low level refined products such as bunker fuel. Significantly, in spite of increasing domestic demand in South America for oil, a high percentage of South American production has continued to be exported, in 1989 slightly less than $20 \%$ of total production going to the United States, in comparison to twenty years earlier, when the percentage was $6 \%$, or to the $20 \%$ of production that was exported to the U.S. in 1950 . For Venezuela specifically, the volume of exports to the United States in the past forty years has varied from $19.5 \%$ in 1950 to $7 \%$ in 1979 and $26 \%$ in $1989 .{ }^{38}$

\section{IX: Trade and Investment Liberalization in Latin America:}

Given the importance of oil to national security and economic development as well as to international trade, debate over foreign investment in the industry has historically been intense. Almost every country in South America, in addition to having a state oil company with varying degrees of control over the industry, has restrictions on foreign investment, but those restrictions in the course of the 1980s and early 1990s have given way to more liberal regimes. The degree of liberalization varies from country to country in all areas of foreign investment. Liberalization has been both a response to strong pressures from the United States as well as part of a shifting political and economic paradigm in which there is a more positive attitude toward foreign investment as an agent of economic development.

Chile, in the aftermath of the coup that overthrew Salvador Allende in 1973, was among the first to permit generally unrestricted foreign investment. Bolivia has signed agreements with the Overseas Private Investment Corporation and the Multilateral Investment Guarantee Agency to allow foreign guarantees in order to promote investment. Peru stands at the opposite end of the spectrum from Chile. Peru's military government nationalized major holdings of Standard Oil in 1968 and in 1985 nationalized all major foreign oil producers. Brazil adopted a new constitution in 1987 that is formally hostile to foreign investment. Colombia has moved toward liberalization in some areas, although the approach in the oil industry remains encouragement of joint ventures. ${ }^{39}$

As the region's major producer, the position of Venezuela is critical. In this case Venezuela has moved toward a more welcoming position, introducing a debt for equity swap

\footnotetext{
${ }^{38}$ United States, Department of Energy.

${ }^{39}$ Williamson, ed., Latin American Adjustment, p. 375.
} 
arrangement that was first employed in early $1989 .^{40}$ The state oil company, PDV, turned at the end of the 1980s toward a more aggressive expansionist stance at home and abroad. PDV accordingly signed letters of intent with a number of foreign companies in the course of 1990-91, including Conoco, to establish strategic alliances between them and PDV to develop and market heavy and extra heavy oil reserves. Venezuela was also expecting to reach agreement with such major Japanese investors as Mitsubishi. ${ }^{41}$

It should be recognized that DFI has not been only from the United States into South America. The wealth generated in Venezuela, for instance, through oil production has enabled Venezuela to invest significantly in the United States. Since early 1990 the Venezuelan state oil company, PDV, has been the sole owner of Citgo, the operations of which include Champlin Refining and Chemicals. Citgo has refineries and petrochemical plants in Louisiana and Texas; it controls over ten thousand service stations in the United States; it also controls Seaview Oil Company, which is a refining and product marketing company. In the mid-west, PDV owns half the equity in Uno-Ven, which has refining, petrochemical and marketing facilities near Chicago. PDV has expanded further expanded its investments in the Caribbean, as well as in the Far East, in the latter in cooperation with BP and Mitsubishi, and in refining in East Germany. PDV has also under way an extensive domestic expansion program, which some Venezuelans fear will necessitate foreign investment and threaten the enviable self-financing position in which PDV has found itself since its creation in the nationalization of 1976. In addition, its expansion plans depended on the fulfilment of its market prediction that the international market will require additional volumes before the year $2000 .{ }^{42}$

\section{X: The Bolivian Experience:}

Bolivia provides another example in which there is considerable interest in joint venture capital and exploration contracts with foreign enterprise. During the 1980 s there was an improvement in Bolivia of the general political and economic climate as well as legislation designed to attract foreign investment and stimulate exploration. In 1985 President Victor $\mathrm{Paz}$ Estenssoro introduced basic economic reforms designed to encourage foreign investment and strengthen the private sector. The measures included a removal of controls on foreign exchange, interest rates and most prices. the government abolished industry-wide collective bargaining, slashed subsidies to fuel prices, utility rates and state-owned corporations.

\footnotetext{
${ }^{40}$ Tbid.

${ }^{41}$ Petroleum Economist, December 1991, p. 43.

${ }^{42}$ Petroleum Economist, December 1991, pp. 26-27.
} 
When these measures accomplished little significant change, except to reduce drastic levels of inflation, the subsequent government of Jaime Paz Zamora specifically targeted increased foreign investment, with the objective of raising its level as a factor in GDP from $12 \%$ to $13.5 \%$ in 1993. Paz Zamora took Bolivia into GATT and engaged in a general lowering of tariff rates. The tariff rate on imported capital goods essential for industrial development has been cut in half (from $10 \%$ to $5 \%$ of value). One result of tariff reform was a $55 \%$ increase in the value of exports and a 59\% increase in imports between 1988 and 1991. Private firms accounted for almost $50 \%$ of export earnings by the end of 1991, in contrast to only $5 \%$ in 1985 . The country has also liberalized its previous regulations for import licensing, now requiring licenses for imports of major competitive agricultural items, including wheat and sugar, and for national security goods. ${ }^{43}$

Zamora's government has also introduced a new mining code that offers more attractive tax rules and removes restrictions on foreign participation. The law provides for guarantees of investments and recognizes international agencies for dispute resolution. In 1991 Bolivia introduced a new hydrocarbons law which authorizes YPFB to enter into joint ventures with private firms and contract companies to take over YPFB fields and operations, including refining and transportation. ${ }^{44}$ Bolivia was one of the first Latin American countries (along with Mexico) to sign a bilateral framework agreement establishing a U.S.Bolivia Trade and Investment Council. Bolivia was also one of the first beneficiaries of the Enterprise for the Americas Initiative; in August 1991 the U.S. eliminated $\$ 371$ million in debt owed by the Bolivian government, and in September 1991 the IDB approved an investment sector loan. ${ }^{45}$

Investment guarantees, trade liberalization and debt reduction in Bolivia have attracted new investment in the oil and gas sector. The government's target for public investment in hydrocarbons was $\$ 117$ million (US) in comparison with only $\$ 10.7$ for education. ${ }^{46}$ YPFB itself in 1988 unveiled a ten year investment plan (1988-1997) valued at $\$ 2$ billion (US). Approximately $\$ 440$ million of that investment is targeted for investment in

${ }^{43}$ Hatfield, "Bolivia's New Legislation Attracts Foreign Investment," Business America (23 March 1992), p. 19.

${ }^{44}$ Laura Hatfield, U.S. Department of Commerce, "Bolivia's New Legislation Attracts Foreign Investment," Business America (23 March 1992), pp. 19-20.

${ }^{45}$ Business Latin America (22 October 1990), p. 337; Laura Hatfield, "Bolivia's New Legislation Attracts Foreign Investment," Business America (23 March 1992), p. 19.

${ }^{46}$ Economist Intelligence Unit, Country Profile: Bolivia, no. 3 (1992). 
the sub-Andean and Altiplano basins. An additional $\$ 1$ billion is being allocated to drilling, and $\$ 480$ million to a pipeline and power export project with Brazil. ${ }^{47}$

Foreign investment in Bolivia has been encouraged by trade and investment liberalization as well as by the promise of potential discoveries from new exploration in the country. Occidental Petroleum, for instance, in 1989 signed an agreement with YPFB for exploration and development of the Madre de Dios region, involving a commitment to invest $\$ 210$ million (US) over a four year period. In 1991 Occidental sold its interest to Diamond Sol OBI (a joint venture between Diamond Shamrock (US) and Sol Petroleo (Argentina). In 1991 YPFB signed contracts with a number of foreign firms. Texaco led its second consortium (with Exxon and Shell) into the Madidi Block, 120 miles from La Paz. It has a two year work commitment that includes 230 line miles of seismic. Phillips Petroleum singed an agreement for work in the Altiplano area of western Bolivia. Others active include Santa Fe Energy, Chevron, Maxus and Mobil. Exploration under the auspices of these firms showed increased activity in 1991-92, with a number of successes, one in Tarija and a second at Chapare.

\section{XI: Argentina:}

Argentina provides a good example of the thrust toward privatization in Latin America in the new liberalization, international mood that is increasingly characteristic of the region. The Argentine government set a target of $\$ 3.5$ billion of state assets to be privatized in the course of 1992, including the sale of $20 \%$ of the shares in YPF and the sale of Gas del Estado, the state natural gas monopoly. The government is also in the process of asking foreign companies to bid on exploration rights in all of the nation's sedimentary basins, on and off-shore. Under regulations introduced by the government of Carlos Menem, YPF will no longer be a shareholder in all fields and those companies who bring in production will not be restricted in the sale of oil in Argentina or in foreign markets. ${ }^{48}$

\section{XII: Colombia:}

Colombia provides a further illustrative example of the Latin American approach to oil development. Although Colombia was never one of the world's leading producers, it was self-sufficient in oil products until 1976, when it became a net importer because of increased

${ }^{47}$ IDB Project Report, BO-0147, 27 February 1989. YPFB by the early 1990s had concluded a number of exploration contracts with foreign enterprise, including Mobil, Chevron, Texaco, Santa Fe Energy Resources, British Petroleum, Shell, a German company, Anschutz, a TexacoSun Oil consortium, Phillips Petroleum, and Exxon.

\footnotetext{
${ }^{48}$ Petroleum Economist, December 1991, p. 43.
} 
demand and declining reserves. That situation altered again in 1985 following the major discoveries by Occidental Petroleum in association with ECOPETROL in the Cravo Norte field in Arauca near the Venezuelan border in northeast Colombia. That was followed by the major Cusiana discovery by British Petroleum in 1991. Some estimates place Cusiana's potential reserve at 3-5 billion barrels, although Ecopetrol itself is more cautious; nevertheless, these new discoveries have quadrupled recoverable reserves.

Although nationalization of the oil industry was rejected as a viable option in the 1960 s, the Colombian government approach for the past two decades has been to encourage joint ventures and associational contracts between ECOPETROL and foreign enterprise. Thus, in the case of the Orito fields, Gulf Oil's shares were purchased in 1973 by a consortium formed by ECOPETROL. The associational contract system became the basis for foreign company operations in Colombia after 1974. By 1989 there were almost one hundred such contracts in place. For contracts that involve exploration in high risk areas, ECOPETROL shares the exploration risk by contributing a portion of the required investment, and in return receives a proportionally larger share of any resulting production. ${ }^{49}$ Clearly, the Colombian approach to oil and natural gas development has not discouraged foreign investment from playing an active role in the country. There was a sharp increase in foreign investment in the oil industry in 1984-86 from less than $\$ 150$ million (US) to almost $\$ 500$ million; it then fell sharply again to $\$ 150$ million in 1987 , then climbed slowly to $\$ 200$ million in 1988 , where it remained through 1991 . The $\$ 3.2$ billion in accumulated foreign investment in petroleum represented $50 \%$ of accumulated foreign investment in the country for the period 1971-1991, in contrast to $\$ 1.6$ billion in all other sectors except mining. ${ }^{50}$

The legal structure within which foreign investment has taken place in the oil industry of Colombia has been gradually liberalized in the course of the 1980s and 1990s. Law 9 of 1991 reflects the prevailing Colombian legal context within which foreign investors operate. $^{51}$ That law conforms to the longstanding national treatment objectives of United States foreign economic policy, ie., no discrimination against foreign investment. The foreign exchange rights of the investor effective at the time of the investment may not be modified in any way detrimental to the investor, except temporarily should the international reserves fall below three months of imports. Colombian law provides for unrestricted remission abroad of net profits by foreign investors. Further, with the objective of internationalizing the Colombian economy, the new import requirements and procedures have

${ }^{49}$ Canadian Embassy, Bogotá, Colombia, "Colombia: Report on the Oil and Gas Industry."

${ }^{50}$ Republic of Colombia, National Planning Department, Mining and Petroleum Investment in Colombia (Bogotá: Peat Marwick, 1992), pp. 140, 141.

${ }^{51}$ Republic of Colombia, National Planning Department, Mining and Petroleum Investment in Colombia (Bogotá: Peat Marwick, 1992), pp. 13-23. 
been simplified to provide for free importation of new goods, the only requirement being registration of the goods with the Colombian Foreign Trade Institute. No foreign exchange reimbursement is permitted for imports by foreign mining and oil companies, covering capital goods and spare parts and materials to be used in such industries, or for imports by service companies involved in mining and oil exploration and exploitation. There is taxation on foreign investment profits, although the level of taxation has shown a downward trend in an effort to attract foreign investment. Dividends or partnership profits obtained by foreign branches or other companies, or individuals not domiciled in Colombia are subject to income taxes at a rate of $19 \%$ for $1991-92,15 \%$ for $1993-95$, and $12 \%$ after 1996 . The capital gains tax was largely eliminated in $1992 .{ }^{52}$

With the purpose of promoting foreign capital flows, Colombia is also in the process of supplementing its legal framework with the adoption of international agreements for the protection of investments against non-commercial risks. Particularly important are the activities undertaken by the Overseas Private Investment Corporation, consultations made for the operation of the Multilateral Investment Guarantee Agreement, the International Center for Settlement of Investment Disputes, and development of bilateral agreements for investment protection and promotion. The Overseas Private Investment Corporation has guaranteed investments in Colombia since 1985.

Overall, investment in the Latin American oil industry has shown a steady increase in the 1989-1992 period, with anticipated more dramatic increases during the next half decade. ARPEL data ${ }^{53}$ indicate that total investment in the industry in 1989 was $\$ 7.3$ billion; in 1990 it rose slightly to $\$ 8$ billion, and to $\$ 9$ billion in 1991 ; but the expected average investment for $1992-96$ is $\$ 15.8$ billion, reflecting investor confidence, investment liberalization, and expanded exploration and development in producing countries.

These constitute only some examples of the degree of liberalization that has taken place in the investment regime in South America in the past decade. Those modifications represent a dramatic shift in policy from even the 1970 s, a lowered degree of hostility toward the foreign sector, a perception that foreign investment and cooperation with foreign enterprise is the most effective route to development.

\section{XIII: Latin American Trade:}

In the area of trade, an important internal or regional trade in oil and oil products has also emerged in Latin America as the region has achieved a higher degree of economic

${ }^{52}$ Colombia, Ministry of Mines and Energy, Mining and Petroleum Investment in Colombia, pp. 54, 55 .

${ }^{53}$ See appendices. Data courtesy of ARPEL. 
development. In the first quarter of $199147 \%$ of Latin American production was exported outside the region, but $9 \%$ was exported within the region and $44 \%$ was used domestically. In terms of consumption, $20 \%$ of Latin America's imports of oil and oil products are derived from outside the region, while $14 \%$ come from regional imports, and $44 \%$ from individual production. ${ }^{54}$

When one considers the basic movement of oil in the western hemisphere, there have been significant changes in the past twenty years. In 1975 the United States exported 65 thousand barrels per day to Latin America and received almost 2.3 million barrels. In the same year the internal trade in oil within Latin America was 120 thousand barrels a day. By 1982 the United States exported 315 barrels a day to Latin America and imported 2 million barrels. In the latter year Latin America's internal trade in oil had risen to 415 thousand barrels a day. In 1975 Latin American producers exported only 20 thousand barrels a day to Japan; by 1990 that had increased almost 7 times to 158 thousand barrels a day. During the same years, Latin America has also exported oil to Canada, ranging from a high of 320 thousand barrels a day in 1976 to a low of 50 thousand barrels a day in $1987 .{ }^{55}$

\section{Conclusions:}

Such developments in investment and trade coincide with the launching of President George Bush's and the IDB's Enterprise for the Americas Initiative. The philosophical underpinnings of that plan are tied to a development model that enshrines private sector initiative, and there is little doubt that the basic orientation in the oil and gas industry in the Western Hemisphere is now toward private sector initiative and control, with variations on state involvement in Mexico, Colombia, Bolivia and Canada. The precise shape of the Western Hemisphere as regional trade blocks emerge, as trade and investment controls are liberalized remains to be seen. At this stage, with a NAFTA reaching conclusion and with Mexico and other Latin American countries striking out on their own to negotiate trade agreements, and with a higher degree of economic modernization taking effect in Latin America, it is likely that one will see expanded hemispheric trade and increased investment in Latin America from outside the region, in particular from the European Community and Japan, but also increased involvement in Latin America by Canadian industry.

Whether rapid trade liberalization is the most effective to economic development remains somewhat controversial. Sabastian Edwards, writing in Contemporary Policy Issues, noted that supporters of the Baker Plan and the IMF have argued that "rapid trade liberalization coupled with devaluation, privatization, and financial reform is the most reasonable strategy." Edwards suggests that more consideration needs to be given to the

${ }^{54}$ ARPEL, Newsletter, Enero-Marzo 1992.

${ }^{55}$ American Petroleum Institute, Basic Petroleum Data Book. Petroleum Industry Statistics, vol. XII, No. 1 (January 1992). 
"short-run trade-offs between these liberalization reforms ... and the overall programs' other objectives, including disinflation." $56 \quad$ Edwards' argument is that most of the traditional literature on trade liberalization has failed to take into consideration the implications of liberalizing trade in a context of high external debt, and he contends that in less developed countries trade liberalization in itself will be unlikely to attract voluntary capital inflows. He acknowledges that countries which have adhered to outward-looking development policies have outperformed those that have been restrictionist and have concentrated on import substitution, but citing the cases of Chile, Korea and Colombia, he argues that there is neither a theoretic model nor empirical evidence linking extremely low or zero tariff levels to higher economic growth. This is an area that will require additional investigation by economists as one examines the relationship between liberalization of trade and investment in the oil industry with economic growth in Latin America and the western hemisphere more generally.

The evidence indicates that investment in the oil industry depends more on factors other than tariffs, including exploration costs, royalty levels, world oil demand and prices, and potential for profit. Consequently, one sees in the current economic climate major corporations shifting their geographic priorities within the western hemisphere and in other promising areas of the world. Two recent examples that have affected Canada include Gulf Oil's decision not to proceed with their involvement in the Hibernia project and British Petroleum Company's decision to sell BP Canada. In the case of Gulf Oil, it is interested in possible involvement in Russian oil and gas development. In the case of BP, it has found western Canada a high cost area of involvement; its recent major discoveries in Colombia and in deep waters of the Gulf of Mexico, along with its key producing areas in the North Sea and Alaska are simply more promising than in Canada. ${ }^{57}$ Thus, trade and investment liberalization in Canada and other areas of the western hemisphere in the 1980s and early 1990 s has not been the decisive factor in determining investment patterns in the industry. Hence, it may seem ironic in that context that within Canada alone more than $\$ 4$ billion in assets are for sale. Oil and to some extent natural gas, because of the high level of strategic importance of the commodity constitutes a special case.

\footnotetext{
${ }^{56}$ Sebastian Edwards, "Debt Crisis, Trade Liberalization, Structural Adjustment, and Growth: Some Policy Considerations," Contemporary Policy Issues, vol. VII (July 1989), 30-31. For other work on this theme see Mario I. Blejer, "Liberalization and Stabilization Policies in the Southern Cone Countries: An Introduction," Journal of Interamerican Studies and World Affairs, vol. 25, No. 4 (November 1983); in the same issue, Jan Peter Wogart, "Combining Price Stabilization with Trade and Financial Liberalization Policies: The Argentine Experience, 19761981;" James Hanson and Jaime de Melo, "The Uruguayan Experience with Liberalization and Stabilization, 1974-1981;" Roberto Zahler, "Recent Southern cone Liberalization Reforms and Stabilization Policies: The Chilean Case, 1974-1982."
}

${ }^{57}$ The Globe and Mail, Report on Business, p. 1. 